\title{
Analisis Perputaran Piutang Dan Perputaran Aktiva Tetap Terhadap Profitabilitas Pada PT. Gudang Garam.Tbk
}

\author{
Susan Rachmawati \\ AMK BSI Jakarta \\ susan.srw@bsi.ac.id
}

\begin{abstract}
Abstrak Perputaran piutang merupakan lamanya piutang untuk berubah menjadi kas sehingga dapat digunakan untuk membiayai biaya operasional perusahaan. Sedangkan perputaran aktiva tetap digunakan untuk mengukur efisiensi penggunaan aktiva tetap dalam menunjang kegiatan penjualan perusahaan. Return on asset (ROA) adalah kemampuan perusahaan untuk menghasilkan laba dari aktiva yang digunakan. Berdasarkan pengertian tersebut dapat dikatakan bahwa perputaran piutang dan perputaran aktiva tetap memiliki peran yang sangat penting dalam menjalankan kegiatan perusahaan untuk menghasilkan profitabilitas. Oleh karena itu maka penulis menganalisa mengenai perputaran piutang, perputaran aktiva tetap dan profitabilitas (ROA) serta meneliti apakah perputaran piutang dan perputaran aktiva tetap memiliki pengaruh terhadap profitabilitas (ROA) yang dimiliki oleh PT. Gudang Garam, Tbk baik secara parsial maupun simultan. Metode penelitian yang digunakan yaitu analisis deskriptif kuantitatif dengan melakukan analisa regresi berganda.Hasil yang diperoleh PT. Gudang Garam, Tbk hanya berhasil mengubah 1 kali piutang menjadi kas pada rata-rata piutang awal dan akhir tahun; kurang memanfaatkan aktiva tetap dalam meningkatkan penjualan; perkembangan profitabilitas cukup baik untuk kurun waktu 6 tahun;perputaran piutang tidak memiliki pengaruh terhadap ROA akan tetapi apabila secara simultan perputaran piutang memiliki pengaruh terhadap ROA sebesar 95,9\%
\end{abstract}

Kata Kunci Perputaran Piutang, Perputaran Aktiva Tetap, ROA

\section{PENDAHULUAN}

Modal kerja adalah" investasi perusahaan jangka pendek seperti kas,surat berharga, piutang dan inventori atau seluruh aktiva lancar" (Putra, 2012 dalam Bramasto, 2007). Modal kerja sangat berperan dalam kegiatan operasional perusahaan karena kelebihan modal kerja akan mengakibatkan banyaknya dana yang tidak terpakai (menganggur) akan tetapi apabila modal kerja kurang akan menghambat kegiatan operasional perusahaan yang akan berpengaruh terhadap profitabilitas perusahaan.

"Terdapat tiga komponen modal kerja yaitu kas, piutang, dan persediaan. Ketiga komponen modal kerja tersebut dapat dikelola dengan cara yang berbeda untuk memaksimalkan profitabilitas atau untuk meningkatkan pertumbuhan perusahaan" (Lazaridis dan Tryfonidis, 2006 dalam Bramasto, 2007)

Aktiva perusahaan merupakan harta yang dimiliki perusahaan dan dapat digunakan untuk operasional perusahaan. Aktiva terbagi menjadi dua yaitu aktiva lancar dan aktiva tetap. Aktiva 
lancar dapat digunakan untuk kegiatan operasional perusahaan diantaranya kas, piutang dagang, persediaan dan lain-lain, sedangkan aktiva tetap terdiri dari tanah, gedung, peralatan, kendaraan dan lain-lain. Sedangkan menurut Bramasto (2007) "aktiva digunakan untuk mendukung kegiatan usaha dan berfungsi untuk mendukung dalam menjalankan kegiatannya dalam rangka memperoleh dana". Selain itu Bramasto (2007) juga menyatakan bahwa "aktiva memiliki tiga karakteristik utama yaitu, memiliki manfaat ekonomi dimasa mendatang, dikuasai oleh suatu unit usaha, hasil dari transaksi masa lalu".

"Permodalan merupakan masalah utama yang akan menunjang kegiatan operasional perusahaan dalam rangka mencapai tujuannya. Modal yang dipergunakan untuk kegiatan usaha ini disebut modal kerja. Modal kerja merupakan kekayaan atau aktiva yang diperlukan oleh perusahaan untuk menyelenggarakan kegiatan operasional sehari-hari yang selalu berputar dalam periode tertentu. Perputaran modal kerja yang rendah bisa disebabkan karena 3 hal, salah satunya adalah rendahnya perputaran piutang". (Sufiana dan Purnawati, 2013)

Perputaran piutang adalah lamanya piutang berubah menjadi kas sehingga dapat digunakan untuk biaya operasional perusahaan. Piutang timbul dari adanya transaksi penjualan barang atau jasa secara kredit sehingga semakin besar penjualan barang atau jasa secara kredit yang dilakukan maka semakin besar pula piutang yang dimiliki oleh perusahaan. Saat ini piutang merupakan salah satu cara yang dapat digunakan untuk meningkatkan volume penjualan dan meningkatkan laba perusahaan.

Profitabilitas adalah kemampuan perusahaan memperoleh laba dalam hubungannya dengan penjualan, total aktiva maupun modal sendiri (Sartono, 2010:122 dalam jurnal 4)

Terdapat beberapa alat ukur yang dapat digunakan untuk menilai besarnya profitabilitas yaitu return on assets (ROA) dan return on equity (ROE) (Bramasto, 2007). Untuk penelitian ini penulis menggunakan ROA sebagai alat ukur yang diguanakan untuk menilai besarnya profitabilitas.

\section{Perumusan masalah}

Berdasarkan latar belakang tersebut maka penulis membuat rumusan masalah dari penelitian ini, diantaranya: 1) Bagaimana tingkat perputaran piutang dan tingkat perputaran aktiva tetap pada PT. Gudang Garam, Tbk; 2) Bagaimana nilai profitabilitas (ROA) pada PT. Gudang Garam, Tbk; 3) Apakah ada pengaruh parsial antara perputaran piutang terhadap profitabilitas (ROA); 4) Apakah ada pengaruh parsial antara perputaran aktiva tetap terhadap profitabilitas (ROA); 5) apakah ada pengaruh secara simultan antara perputaran piutang dan perputaran aktiva tetap terhadap profitabilitas (ROA)

\section{LANDASAN TEORI}

\section{A. Piutang}

Menurut Bambang Riyanto (2008;85) dalam Bramasto (2007) mengemukakan bahwa "penjualan kredit tidak segera menghasilkan penerimaan kas, tetapi menimbulkan piutang langganan. Piutang merupakan hak untuk menagih sejumlah uang dari si penjual kepada si pembeli yang timbul karena adanya suatu transaksi”. Menurut Ikatan Akuntan Indonesia dalam buku PSAK No. 9 : "Bahwa sumber terjadinya piutang digolongkan dalm dua kategori, yaitu piutang usaha dan piutang lain-lain. Piutang usaha meliputi piutang yang timbul karena penjualanpenjualan pokok atas penyerahan jasa dalam rangka kegiatan usaha normal perusahaan. Piutang yang timbul dari transaksi di luar usaha kegiatan perusahaan digolongkan piutang lain-lain".

Perputaran piutang adalah "rasio yang memperlihatkan lamanya waktu untuk mengubah piutang menjadi kas" (Bambang riyanto, 2008:90) dalam Bramasto (2007). "Putaran piutang dihitung dengan membagi penjualan kredit bersih dengan saldo rata-rata piutang. Piutang yang dimiliki oleh suatu perusahaan mempunyai hubungan erat dengan volume penjualan kredit. Posisi piutang dapat dihitung dengan menggunakan rasio perputaran piutang"(bramasto, 2007). Perputaran piutang dihitung dengan rumus : 


$$
\text { Perputaran Piutang }=\quad \frac{\text { Piutang dagang/usaha }}{\text { Piutang rata-rata }}
$$

\section{B. Aktiva Tetap}

Rasio perputaran aktiva tetap digunakan oleh manajemen perusahaan untuk mengukur efisiensi penggunaan aktiva tetap dalam menunjang kegiatan penjualan perusahaan. Menurut Munawir (2004:240) dalam Bramasto (2007), mengemukakan bahwa : "Perputaran Aktiva Tetap (Fixed Assets Turn Over) yaitu rasio antara penjualan dengan aktiva tetap bersihnya."

Dapat juga di rumuskan dengan :

Perputaran aktiva tetap $=\frac{\text { Penjualan }}{\text { Aktiva bersih }}$

Sumber: Munawir(2004:240) dalam Bramasto (2007)

Sedangkan menurut R. Agus Sartono (2002; 120) dalam Bramasto (2007), menjelaskan bahwa : "Perputaran aktiva tetap adalah rasio antara penjualan dengan aktiva tetap neto. Rasio ini menunjukan bagaimana perusahaan menggunakan aktiva tetapnya seperti gedung, kendaraan, mesin-mesin, perlengkapan kantor."

Rasio perputaran aktiva tetap dihitung dengan rumus :

Perputaran aktiva tetap $=\frac{\text { Penjualan }}{\text { Aktiva tetap }}$

\section{Profitabilitas (ROA)}

Profitabilitas adalah kemampuan perusahaan dalam memperoleh laba.(Santoso, 2013)

Return on investment (ROI), menunjukkan kemampuan perusahaan menghasilkan laba dari aktiva yang digunakan.(Yuli, 2009)

Rasio Kemampulabaan (Profitability Rasio) menggambarkan kemampuan suatu perusahaan dalam menghasilkan laba secara relatif. Relatif disini artinya laba tidak diukur dari besarnya secara mutlak, tetapi diperbandingkan dengan unsur-unsur tolok ukur lainnya, karena perolehan laba yang besar belum tentu menunjukkan kemampulabaan yang juga besar. Pengukuran kinerja keuangan perusahaan dengan ROA menunjukkan kemampuan atas modal yang diinvestasikan dalam keseluruhan aktiva yang dimiliki untuk menghasilkan laba. ROA (Return On Asset) adalah rasio keuntungan bersih setelah pajak untuk menilai seberapa besar tingkat pengembalian dari asset yang dimiliki oleh perusahaan. ROA yang negatif disebabkan laba perusahaan dalam kondisi negatif pula atau rugi. Hal ini menunjukkan kemampuan dari modal yang diinvestasikan secara keseluruhan belum mampu untukmenghasilkan laba. (Rahayu, 2014)

Rasio ini menggambarkan perputaran aktiva diukur dari volume penjualan. Semakin besar rasio ini semakin baik. Hal ini berarti bahwa aktiva dapat lebih cepat berputar dan meraih laba. (Kasmir, 2011:199 dalam Santoso, 2013)

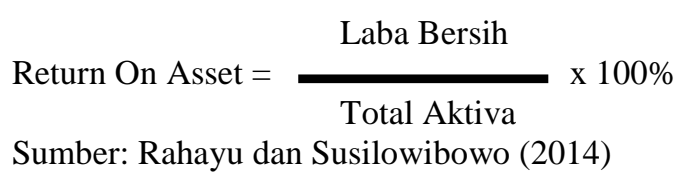




\section{METODOLOGI PENELITIAN}

Metode Penelitian yang penulis gunakan adalah tehnik analisa deskriptif kuantitatif dengan cara melakukan analisa regresi linear berganda. Sampel perusahaan yang penulis ambil adalah PT. Gudang Garam, Tbk periode 2013 hingga 2018 dengan sistem pencatatan laporan keuangan kuartal.

\section{HASIL PENELITIAN}

1. Analisis Perputaran Piutang

Tabel 4.1 Perputaran Piutang

\begin{tabular}{|l|r|r|r|}
\hline \multicolumn{4}{|c|}{ Data Perputaran Piutang } \\
\hline Tahun & Piutang Usaha & Rata-Rata Piutang & Perputaran Piutang \\
\hline $2012-4$ & 1.382 .539 & & 1,0265 \\
\hline $2013-1$ & 1.457 .953 & 1.420 .246 & 0,9867 \\
\hline $2013-2$ & 1.419 .754 & 1.438 .854 & 1,0713 \\
\hline $2013-3$ & 1.637 .868 & 1.528 .811 & 1,1456 \\
\hline $2013-4$ & 2.196 .086 & 1.916 .977 & 1,0389 \\
\hline $2014-1$ & 2.374 .074 & 2.285 .080 & 0,9393 \\
\hline $2014-2$ & 2.102 .288 & 2.238 .181 & 0,8675 \\
\hline $2014-3$ & 1.610 .411 & 1.856 .350 & 0,9751 \\
\hline $2014-4$ & 1.532 .275 & 1.571 .343 & 0,9995 \\
\hline $2015-1$ & 1.530 .783 & 1.531 .529 & 0,9339 \\
\hline $2015-2$ & 1.340 .891 & 1.435 .837 & 1,0661 \\
\hline $2015-3$ & 1.530 .558 & 1.435 .725 & 1,0121 \\
\hline $2015-4$ & 1.568 .098 & 1.549 .328 & 1,0369 \\
\hline $2016-1$ & 1.688 .249 & 1.628 .174 & 1,1905 \\
\hline $2016-2$ & 2.483 .036 & 2.085 .643 & 0,8821 \\
\hline $2016-3$ & 1.959 .263 & 2.221 .150 & 1,0323 \\
\hline $2016-4$ & 2.089 .949 & 2.024 .606 & 0,9845 \\
\hline $2017-1$ & 2.025 .989 & 2.057 .969 & 1,0559 \\
\hline $2017-2$ & 3.447 .889 & 2.736 .939 & 2.850 .300 \\
\hline $2017-3$ & 2.252 .710 & 2.240 .904 & 2.361 .150 \\
\hline $2017-4$ & 2.229 .097 & 1.924 .528 & \\
\hline $2018-1$ & 2.493 .203 & & \\
\hline Rata-rata & 1.950 .973 & & \\
\hline
\end{tabular}

Perputaran piutang adalah rasio yang memperlihatkan lamanya untuk mengubah piutang menjadi kas. Putaran piutang dihitung dengan membagi penjualan dengan rata-rata piutang. Ratarata piutang dihitung dengan menjumlahkan piutang awal dengan piutang akhir dan kemudian membaginya menjadi dua. Berdasarkan data yang terkumpul diperoleh gambaran perputaran piutang pada PT.Gudang Garam, Tbk sebagai berikut: Tingkat perputaran piutang dari tahun 2013 
sampai dengan 2018 kuartal 1 mengalami fluktuasi di setiap kuartalnya baik naik ataupun turun dengan nilai rata-rata perputaran piutang sebesar 1,0138 atau dengan kata lain PT. Gudang Garam, Tbk hanya berhasil mengubah piutang menjadi kas sebesar 1 kali rata-rata piutang awal tahun dan akhir tahun.

2. Analisis Perputaran Aktiva Tetap

Tabel 4.2 Perputaran Aktiva Tetap

\begin{tabular}{|c|c|c|c|}
\hline \multicolumn{4}{|c|}{ Data Perputaran Aktiva Tetap } \\
\hline Tahun & Penjualan & Aktiva Tetap & $\begin{array}{c}\text { Perputaran Aktiva } \\
\text { Tetap }\end{array}$ \\
\hline 2013-1 & 12.638 .547 & 11.849 .074 & 1,0666 \\
\hline $2013-2$ & 26.637 .719 & 12.792 .990 & 2,0822 \\
\hline 2013-3 & 40.016 .768 & 13.594 .011 & 2,9437 \\
\hline 2013-4 & 55.436 .954 & 14.788 .915 & 3,7485 \\
\hline 2014-1 & 15.670 .252 & 16.039 .839 & 0,9770 \\
\hline 2014-2 & 32.667 .729 & 16.998 .933 & 1,9218 \\
\hline 2014-3 & 48.189 .776 & 17.795 .721 & 2,7079 \\
\hline 2014-4 & 65.185 .850 & 18.973.272 & 3,4357 \\
\hline $2015-1$ & 15.983 .896 & 19.368 .901 & 0,8252 \\
\hline $2015-2$ & 33.226 .047 & 19.673 .753 & 1,6889 \\
\hline $2015-3$ & 51.011 .835 & 19.975 .638 & 2,5537 \\
\hline 2015-4 & 70.365 .573 & 20.106 .488 & 3,4996 \\
\hline 2016-1 & 17.992 .761 & 20.372 .980 & 0,8832 \\
\hline $2016-2$ & 36.962 .772 & 20.417 .737 & 1,8103 \\
\hline 2016-3 & 56.211 .870 & 20.546 .986 & 2,7358 \\
\hline 2016-4 & 76.274 .147 & 20.498 .950 & 3,7209 \\
\hline $2017-1$ & 19.969 .814 & 20.202 .790 & 0,9885 \\
\hline $2017-2$ & 40.245 .294 & 20.976 .952 & 1,9185 \\
\hline $2017-3$ & 61.523 .113 & 21.003 .198 & 2,9292 \\
\hline $2017-4$ & 83.305 .925 & 21.408 .575 & 3,8912 \\
\hline 2018-1 & 21.980 .863 & 21.171 .762 & 1,0382 \\
\hline Rata-Rata & 41.976 .072 & 18.502 .736 & 2,2556 \\
\hline
\end{tabular}

Berdasarkan tabel 4.2 Terlihat bahwa rata-rata perputaran aktiva tetap mengalami peningkatan di kuartal 2,3,4 dan selalu mengalami penurunan di kuartal 1. Perputaran aktiva tetap mencapai rata-rata 2,2556 atau sama dengan 2,3 kali dalam kurun waktu 2013-2018 kuartal 1. Dilihat dari sudut yang lainnya penggunaan aktiva tetap dapat meningkatkan penjualan tetapi untuk tahun 2014(1); 2015(1); 2016(1); 2017(1) mengalami penurunan dan untuk 2018(1) mengalami kenaikan yang tidak terlalu banyak, hal itu membuktikan bahwa PT. Gudang Garam, Tbk kurang memanfaatkan aktiva tetap dalam meningkatkan penjualannya. 
3. Analisis Nilai Profitabilitas (ROA)

Tabel 4.3 Nilai Profitabilitas (ROA)

\begin{tabular}{|c|c|c|c|}
\hline \multicolumn{4}{|c|}{ Data Profitabilitas (ROA) } \\
\hline Tahun & Laba/ Rugi Bersih & Total Assets & ROA (\%) \\
\hline 2013-1 & 1.062 .802 & 41.739 .067 & 2,55 \\
\hline 2013-2 & 2.231 .732 & 45.450 .611 & 4,91 \\
\hline 2013-3 & 3.277 .375 & 47.767 .800 & 6,86 \\
\hline 2013-4 & 4.383 .932 & 50.770 .251 & 8,63 \\
\hline 2014-1 & 1.434 .936 & 52.470 .532 & 2,73 \\
\hline 2014-2 & 2.734 .946 & 53.839 .153 & 5,08 \\
\hline 2014-3 & 4.067 .582 & 56.579 .914 & 7,19 \\
\hline 2014-4 & 5.368 .568 & 58.220 .600 & 9,22 \\
\hline 2015-1 & 1.286 .515 & 59.699 .967 & 2,15 \\
\hline $2015-2$ & 2.409 .076 & 59.343 .354 & 4,06 \\
\hline 2015-3 & 4.114 .147 & 59.341 .389 & 6,93 \\
\hline 2015-4 & 6.452 .834 & 63.505 .413 & 10,16 \\
\hline 2016-1 & 1.702 .521 & 63.260 .429 & 2,69 \\
\hline $2016-2$ & 2.287 .008 & 63.529 .940 & 3,60 \\
\hline 2016-3 & 4.597 .751 & 62.817 .278 & 7,32 \\
\hline $2016-4$ & 6.672 .682 & 62.951 .634 & 10,60 \\
\hline 2017-1 & 1.890 .130 & 59.490 .774 & 3,18 \\
\hline $2017-2$ & 3.125 .134 & 62.364 .930 & 5,01 \\
\hline 2017-3 & 5.419 .448 & 62.797 .627 & 8,63 \\
\hline $2017-4$ & 7.755 .347 & 66.759 .930 & 11,62 \\
\hline 2018-1 & 1.892 .695 & 63.304 .028 & 2,99 \\
\hline Rata-rata & 3.531 .770 & 57.904 .982 & 6,01 \\
\hline
\end{tabular}

Profitabilitas menurut R. Agus Sartono (2005:130) dalam jurnal (Sufiana dan Purnawati : 2013) adalah kemampuan perusahaan memperoleh laba dalam hubungan dengan penjualan, total aktiva maupun modal sendiri. Rasio profitabilitas ini akan memberikan gambaran tentang tingkat kemakmuran perusahaan, dengan semakin tingginya profitabilitas perusahaan berarti semakin baik posisi perusahaan di lihat dari segi pemanfaatan assetsnya. Dilihat dari pernyataan itu, dapat dikatakan bahwa perkembangan ROA PT. Gudang Garam, Tbk dalam kurun waktu 6 tahun dapat dikatakan cukup baik walau secara kadang mengalami penurunan pada tahun 2014(1); 2015(1); 2016(1); 2017(1) dan 2018(1). Dikatakan cukup baik karena rasio profitabilitas yang didapat perusahaan cederung naik dalam kurun waktu tersebut.

\section{Uji Normalitas}

Uji normalitas dilakukan bertujuan untuk melihat apakah data memunyai distribusi atau penyebaran secara normal atau tidak di dalam model regresi. Model regresi yang baik memiliki data yang terdistribusi secara normal. Salah satu cara untuk melihat data yang digunakan dalam 
penelitian terdistribusi secara normal atau tidak adalah melalui uji Kolmogorov-Smirnov (K-S). Hasil pengujian normalitas dapat dilihat melalui Tabel berikut:

Tabel 4.4

Uji Normalitas

One-Sample Kolmogorov-Smirnov Test

\begin{tabular}{|c|c|c|}
\hline & & $\begin{array}{c}\text { Unstandardized } \\
\text { Residual }\end{array}$ \\
\hline \multicolumn{2}{|l|}{$\mathrm{N}$} & 21 \\
\hline \multirow{3}{*}{ Normal Parameters ${ }^{\mathrm{a}, \mathrm{b}}$} & Mean &, 0000000 \\
\hline & Std. Deviation &, 59884722 \\
\hline & Absolute &, 102 \\
\hline \multirow[t]{2}{*}{ Most Extreme Differences } & Positive & ,088 \\
\hline & Negative &,- 102 \\
\hline Kolmogorov-Smirnov Z & & ,466 \\
\hline Asymp. Sig. (2-tailed) & & ,982 \\
\hline
\end{tabular}

a. Test distribution is Normal.

b. Calculated from data.

Dari hasil uji normalitas diketahui bahwa nilai signifikansi (Asymp.Sig 2 - tailed) sebesar 0,982 . Karena signifikansi lebih dari $0,05(0,982>0,05)$ maka nilai residual terdistribusi secara normal atau memenuhi asumsi klasik normalitas.

\section{Uji Multikolinieritas}

Uji multikolinearitas bertujuan untuk menguji apakah model regresi ditemukan adanya korelasi antar variabel bebas. Model regresi yang baik adalah tidak terjadi multikolinearitas sempurna. Untuk mengetahui terjadinya multikolinearitas dapat melalui Tolerance dan Variance Inflation Factor (VIF). Kedua ukuran ini menunjukkan setiap variabel bebas manakah yang dijelaskan oleh variabel bebas lainnya. Hasil yang ditunjukan dalam output SPSS maka besarnya tolerance dan VIF dari kedua variabel bebas yang digunakan (perputaran piutang dan perputaran aktiva tetap) dapat dilihat melalui tabel berikut:

Tabel 4.5

Uji Multikolinearitas

\begin{tabular}{|c|c|c|c|}
\hline \multirow{2}{*}{\multicolumn{2}{|c|}{ Model }} & \multicolumn{2}{|c|}{ Collinearity Statistics } \\
\hline & & Tolerance & VIF \\
\hline \multirow{3}{*}{1} & (Constant) & & \\
\hline & Perputaran Piutang & .988 & 1.012 \\
\hline & Perputaran Aktiva Tetap & .988 & 1.012 \\
\hline
\end{tabular}

Berdasarkan tabel di atas nilai tolerance masing-masing variabel lebih dari 0,1 dan nilai VIF masing-masing variabel kurang dari 10 maka dapat disimpulkan bahwa tidak terjadi masalah multikolinearitas pada model regresi.

\section{Uji Koefisien Determinasi}

Berikut merupakan hasil output IBM SPSS 21 dan pengambilan keputusan serta kesimpulan mengenai koefisien determinasi secara parsial dan simultan antara variabel bebas $\left(\mathrm{X}_{1} \& \mathrm{X}_{2}\right)$ terhadap variabel terikat $(\mathrm{Y})$ : 


\section{Uji Koefisien determinasi secara parsial}

Untuk mengetahui adanya pengaruh yang signifikan secara parsial antara variabel bebas (perputaran piutan dan perputaran aktiva tetap) terhadap variabel terikat (ROA), maka peneliti menggunakan uji t.

Tabel 4.6

Uji Koefisien

Coefficients $^{\mathrm{a}}$

\begin{tabular}{|c|c|c|c|c|c|c|}
\hline \multicolumn{2}{|c|}{ Model } & \multicolumn{2}{|c|}{$\begin{array}{l}\text { Unstandardized } \\
\text { Coefficients }\end{array}$} & \multirow{2}{*}{$\begin{array}{c}\text { Standardized } \\
\text { Coefficients } \\
\text { Beta }\end{array}$} & \multirow[t]{2}{*}{$\mathrm{t}$} & \multirow[t]{2}{*}{ Sig. } \\
\hline & & B & Std. Error & & & \\
\hline \multirow{3}{*}{1} & (Constant) & 2.605 & 1.435 & & 1.816 & .086 \\
\hline & Perputaran Piutang & -2.694 & 1.345 & -.096 & -2.003 & .060 \\
\hline & Perputaran Aktiva Tetap & 2.718 & .135 & .965 & 20.210 & .000 \\
\hline
\end{tabular}

a. Dependent Variable: Profitabilitas (ROA)

a. Uji determinasi secara parsial antara perputaran piutang terhadap ROA (uji t)

Hipotesis:

$\mathrm{Ho}_{1}$ : Tidak terdapat pengaruh yang signifikan secara parsial antara perputaran piutang terhadap ROA.

$\mathrm{Ha}_{1}$ : Terdapat pengaruh yang signifikan secara parsial antara perputaran piutang terhadap ROA.

Pengambilan keputusan:

Jika nilai Sig > 0,05 maka Ho ditolak

Jika nilai sig $<0,05$ tabel maka Ho diterima

Berdasarkan tabel Coefficients $^{\mathrm{a}}$ di atas nilai $\mathrm{t}$ untuk perputaran piutang sebesar 2,003 dengan signifikasi diatas $0,05(\alpha)$ yaitu sebesar 0,060. Karena sig > 0,05 maka Ho diterima. Sehingga dapat dikatakan tidak terdapat pengaruh yang signifikan secara parsial antara perputaran piutang terhadap ROA.

b. Uji determinasi secara parsial antara perputaran aktiva tetap terhadap ROA (uji t).

Hipotesis:

$\mathrm{Ho}_{2}$ : Tidak terdapat pengaruh yang signifikan secara parsial antara perputaran aktiva tetap terhadap ROA.

$\mathrm{Ha}_{2}$ : Terdapat pengaruh yang signifikan secara parsial antara perputaran aktiva tetap terhadap ROA.

Pengambilan keputusan:

Jika nilai Sig > 0,05 maka Ho ditolak

Jika nilai sig $<0,05$ tabel maka Ho diterima 
Berdasarkan tabel Coefficients ${ }^{\mathrm{a}} 4.6$ di atas nilai t untuk perputaran aktiva tetap sebesar 20,210 dengan signifikasi dibawah 0,05 $(\alpha)$ yaitu sebesar 0,000. Karena sig < 0,05, maka Ho ditolak dan Ha diterima. Sehingga dapat dikatakan terdapat pengaruh yang signifikan secara parsial antara perputaran aktiva tetap terhadap ROA, yakni sebesar 96,5\%

\section{Uji koefisien determinasi secara simultan}

Untuk mengetahui adanya pengaruh yang signifikan secara simultan antara perputaran piutang dan perputaran aktiva tetap terhadap ROA, maka peneliti menggunakan uji F.

Hipotesis :

$\mathrm{Ho}_{3}$ : Tidak terdapat pengaruh yang signifikan secara simultan antara perputaran piutang dan perputaran aktiva tetap terhadap ROA.

$\mathrm{Ha}_{3}$ : Terdapat pengaruh yang signifikan secara simultan antara perputaran piutang dan perputaran aktiva tetap terhadap ROA.

Pengambilan keputusan :

Jika Sig F change $<0,05$, maka $\mathrm{Ho}_{6}$ diterima.

Jika Sig F Change $>0,05$, maka $\mathrm{Ho}_{6}$ ditolak.

Tabel 4.7

UJI F

\begin{tabular}{|r|r|r|r|r|}
\hline \multicolumn{5}{|c|}{ Change Statistics } \\
\hline $\begin{array}{c}\text { R Square } \\
\text { Change }\end{array}$ & F Change & df1 & df2 & Sig. F Change \\
\hline .959 & 213.026 & 2 & 18 & .000 \\
\hline
\end{tabular}

a. Predictors: (Constant), Perputaran Aktiva Tetap, Perputaran Piutang

b. Dependent Variable: Profitabilitas (ROA)

Berdasarkan tabel diatas, nilai Sig F Change yang diperoleh sebesar 0,000. Karena 0,000< 0,05 atau Sig $\mathrm{F}$ change $<0,05$, maka $\mathrm{Ho}_{6}$ ditolak. Karena Ho ditolak maka Ha diterima. Sehingga dapat dikatakan terdapat pengaruh yang signifikan secara simultan (bersama-sama) antara perputaran piutang dan perputaran aktiva tetap terhadap ROA pada PT. Gudang Garam, Tbk.

Berdasarkan tabel diatas nilai koefisien determinasi secara simultan ( $\mathrm{R}$ square change) yang didapat sebesar 0,959. Hal ini menunjukan bahwa prosentase pengaruh antara variabel bebas (perputaran piutang dan perputaran aktiva tetap) terhadap variabel terikat (ROA) secara simultan sebesar $95,9 \%$. Sementara itu $4,1 \%$ sisanya merupakan pengaruh dari faktor-faktor lain selain dari faktor yang diwakili variabel bebas (perputaran piutang dan perputaran aktiva tetap). 


\section{Estimasi Model Regresi}

Tabel 4.8 Hasil estimasi model regresi

\begin{tabular}{|c|c|c|c|c|c|c|}
\hline \multirow{2}{*}{\multicolumn{2}{|c|}{ Model }} & \multicolumn{2}{|c|}{ Unstandardized Coefficients } & \multirow{2}{*}{$\begin{array}{c}\begin{array}{c}\text { Standardized } \\
\text { Coefficients }\end{array} \\
\text { Beta }\end{array}$} & \multirow[t]{2}{*}{$\mathrm{t}$} & \multirow[t]{2}{*}{ Sig. } \\
\hline & & B & Std. Error & & & \\
\hline \multirow{3}{*}{1} & (Constant) & 2.605 & 1.435 & & 1.816 & .086 \\
\hline & Perputaran Piutang & -2.694 & 1.345 & -.096 & -2.003 & .060 \\
\hline & Perputaran Aktiva Tetap & 2.718 & .135 & .965 & 20.210 & .000 \\
\hline
\end{tabular}

Melalui hasil pengolahan data yang diuraikan pada tabel 4.7 maka dapat dibentuk model prediksi variabel perputaran piutang dan perputaran aktiva tetap terhadap profitabilitas (ROA) sebagai berikut:

$$
Y=2,605-2,694 X_{1}+2,718 X_{2}
$$

\section{Hipotesis:}

a. Jika tidak perubahan pada perputaran piutang dan aktiva tetap maka rasio profibilitas (ROA) sebesar 2,605

b. Jika perputaran piutang bertambah 1 satuan maka mengurangi rasio profibilitas (ROA) sebesar $-2,694$

c. Jika perputaran aktiva tetap bertambah 1 satuan maka menambah rasio profibilitas (ROA) sebesar 2,718

\section{KESIMPULAN}

Berdasarkan hasil pembahasan dapat diberi kesimpulan, sebagai berikut:

1. Tingkat perputaran piutang dari tahun 2013 sampai dengan 2018 kuartal 1 mengalami fluktuasi di setiap kuartalnya baik naik ataupun turun dengan nilai rata-rata perputaran piutang sebesar 1,0138 atau dengan kata lain PT. Gudang Garam, Tbk hanya berhasil mengubah piutang menjadi kas sebesar 1 kali rata-rata piutang awal tahun dan akhir tahun.

2. Perputaran aktiva tetap mencapai rata-rata 2,2556 atau sama dengan 2,3 kali dalam kurun waktu 2013-2018 kuartal 1. Dilihat dari sudut yang lainnya penggunaan aktiva tetap dapat meningkatkan penjualan tetapi untuk tahun 2014(1); 2015(1); 2016(1); 2017(1) mengalami penurunan dan untuk 2018(1) mengalami kenaikan yang tidak terlalu banyak, hal itu membuktikan bahwa PT. Gudang Garam, Tbk kurang memanfaatkan aktiva tetap dalam meningkatkan penjualannya.

3. Perkembangan ROA PT. Gudang Garam, Tbk dalam kurun waktu 6 tahun dapat dikatakan cukup baik walau secara kadang mengalami penurunan pada tahun 2014(1); 2015(1); 2016(1); 2017(1) dan 2018(1). Dikatakan cukup baik karena rasio profitabilitas yang didapat perusahaan cederung naik dalam kurun waktu tersebut.

4. Secara parsial perputaran piutang $\left(\mathrm{X}_{1}\right)$ tidak terdapat pengaruh yang signifikan terhadap rasio ROA $(Y)$ hanya sebesar $9,6 \%$. Secara parsial perputaran aktiva tetap $\left(\mathrm{X}_{2}\right)$ terdapat pengaruh yang signifikan terhadap rasio ROA (Y) yakni sebesar 96,5\%. 
5. Secara simultan (bersama-sama) antara perputaran piutang dan perputaran aktiva tetap mempengaruhi rasio ROA sebesar 95,9\%.

\section{UCAPAN TERIMA KASIH}

Saya mengucapkan banyak terima kasih kepada redaksi jurnal Ekonomi \& Ekonomi Syariah untuk kesempatan yang diberikan kepada saya sehingga artikel ini dapat diterbitkan didalam jurnal Ekonomi \& Ekonomi Syariah ini.

\section{DAFTAR PUSTAKA}

Bramasto, A. (2007). Analisis Perputaran Aktiva Tetap Dan Perputaran Piutang Kaitannya Terhadap Return On Assets Pada Pt. Pos Indonesia (Persero) Bandung. Jurnal Ekonomi Unikom - jurnal.unikom.ac.id http://jurnal.unikom.ac.id/_s/data/jurnal/v09-n02/11-miu-arib.pdf/pdf/11-miu-arib.pdf

Orniati, Yuli. (2009). Laporan Keuangan sebagai Alat untuk Menilai Kinerja Keuangan. Jurnal Ekonomi Bisnis, 2009 - fe.um.ac.id. tahun 14, No. 3 Nopember http://fe.um.ac.id/wp-content/uploads/2010/01/yuli-orniati_4.pdf

Rahayu, Ayu dan Susilowibowo, Joni. (2014). Pengaruh Perputaran Kas, Perputaran Piutang Dan Perputaran Persediaan Terhadap Profitabilitas Perusahaan Manufaktur. Jurnal Ilmu Manajemen (JIM), 2014 - jurnalmahasiswa.unesa.ac.id. Vol 2, No 4 http://jurnalmahasiswa.unesa.ac.id/index.php/jim/article/view/10363/10111

Riduwan. 2012. Dasar - Dasar Statistika. Bandung: Alfabeta.

Santoso, E.E. Clairene. (2013). Perputaran Modal Kerja Dan Perputaran Piutang Pengaruhnya Terhadap Profitabilitas Pada Pt. Pegadaian (Persero). Jurnal Emba: Jurnal Riset Ekonomi, Manajemen, Bisnis dan Akuntansi - ejournal.unsrat.ac.id. Vol. 1 No. 4 https://ejournal.unsrat.ac.id/index.php/emba/article/view/2963/2509

Setiawan, Budi. 2013. Menganalisa Statistik Bisnis dan Ekonomi dengan SPSS 21. Yogyakarta: Andi.

Sufiana, Nina dan Purwanti, Ketut, Ni. (2013). Pengaruh Perputaran Kas, Perputaran Piutang Dan Perputaran Persediaan Terhadap Profitabilitas. e-jurnal Manajemen Universitas Udayana, vol 2 no 4 https://ojs.unud.ac.id/index.php/Manajemen/article/view/4773 